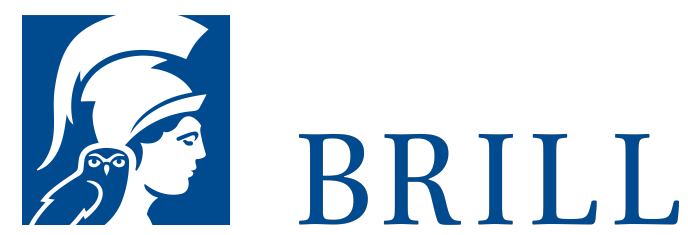

\title{
Der Malinche-Komplex
}

Conquista, Genus, Genealogien

Author: Claudia Leitner

Kann die Subalterne sprechen? - Malinche, die indigene

Übersetzerin und Geliebte Cortés', zeigt die Kernanliegen postkolonialer Theorie in besonderer Dichte und Schärfe an. Über der paradigmatischen Vermittlerin in der Conquista, große Streitfigur mestizisch gesetzter Mexikanität und divergierender Feminismen, neu entdeckte Ikone des kulturellen Austauschs, eröffnen sich beinahe fünf Jahrhunderte des Verhandelns indigener wie auch weiblicher Sprach-, Handlungs- und Kulturfähigkeit. 'Malinche' heißt auch der viertgrößte Berg Mexikos und er mag für die Massivität der Bedeutungsreservoirs stehen, die sich in nun schon fast ein halbes Jahrtausend lang um die Figur der Malinche gelegt haben.

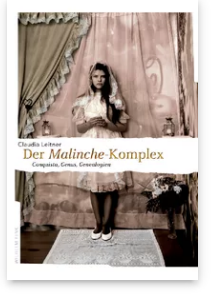

Pages: 336

Seiten, $10 \mathrm{~s} / \mathrm{w}$

Abb.

Language:

German

Subjects:

French \&

Francophone,

Literature and

Cultural Studies

Publisher: Brill |

Fink

E-Book (PDF)

Released online:

O2 Dec 2019

ISBN: $978-3^{-}$

8467-4685-1

List price

USD $\$ 75.00$

Paperback

Publication date:

18 Mar 2009

ISBN: $978-3^{-}$

7705-4685-5

List price

USD $\$ 75.00$ 
For more information see brill.com

Order information: Order online at brill.com +44330 333 0049 | customerservices@brill.com Submission information: brill.com/authors

Titles published by Brill | Fink, Brill | mentis or Brill | Schöningh: +49(o)715413279216| brill@brocom.de 